Louisiana State University

LSU Digital Commons

Faculty Publications

Department of Geology and Geophysics

$1-1-2014$

\title{
Sea-level-induced seismicity and submarine landslide occurrence
}

Daniel Brothers

United States Geological Survey

Karen Luttrell

United States Geological Survey Western Region

Jason Chaytor

United States Geological Survey

Follow this and additional works at: https://digitalcommons.lsu.edu/geo_pubs

\section{Recommended Citation}

Brothers, D., Luttrell, K., \& Chaytor, J. (2014). Sea-level-induced seismicity and submarine landslide occurrence. Geology, 42 (6), 339. https://doi.org/10.1130/G35711Y.1

This Article is brought to you for free and open access by the Department of Geology and Geophysics at LSU Digital Commons. It has been accepted for inclusion in Faculty Publications by an authorized administrator of LSU Digital Commons. For more information, please contact ir@lsu.edu. 


\section{Sea-level-induced seismicity and submarine landslide occurrence}

\author{
Daniel Brothers ${ }^{1}$, Karen Luttrell ${ }^{2}$, and Jason Chaytor ${ }^{1}$ \\ ${ }^{1}$ U.S. Geological Survey, Coastal and Marine Science Center, 384 \\ Woods Hole Road, Woods Hole, Massachusetts 02543, USA \\ ${ }^{2}$ U.S. Geological Survey, Volcano Science Center, 345 Middlefield \\ Road, MS 910, Menlo Park, California 94025, USA
}

We would like to thank Urlaub et al. (2014) for their Comment responding to our paper (Brothers et al., 2013) and continuing a dialog on the important topic of submarine landslide age dating. The processes that lead to submarine slope failure are poorly understood in part due to the limited number of well-dated landslide deposits, yet it is widely accepted that earthquakes play a central role in triggering both submarine and terrestrial landslides. An overarching goal of our paper was to test for a causal relationship between seismicity and rapid sea-level rise. To a firstorder, our results suggested that large $(100+\mathrm{m})$ and rapid $(10+\mathrm{mm} / \mathrm{yr})$ changes in eustatic sea-level can potentially modulate seismicity rates on passive continental margins- regions that experience large earthquakes relatively infrequently. Such a relationship may help tie together processes that precondition slopes to fail, such as increased sediment supply, and processes that actually trigger failure, such as earthquakes. Landslide age dating was not the focus of our analysis. We compiled age data from published sources much like previous studies that also described an apparent increase in landslide frequency following the Last Glacial Maximum (e.g., Owen et al., 2007; Lee, 2009). We focused on the time period between $16 \mathrm{ka}$ and $8 \mathrm{ka}$ because the rate and magnitude of sea-level rise over this period was sufficient to induce lithospheric flexure (Luttrell and Sandwell, 2010). Our paper did not discuss a potential tie between modern sea-level rise and future landslides.

We agree that there is a need to expand the database of landslide ages and a need to critically reevaluate those already in the database. Results by Urlaub et al. (2013) were not published at the time that our manuscript was accepted to Geology. Nevertheless, we fully recognize and commend their rigorous analyses. Given the large uncertainties in landslide agedates and the need for additional landslide age-control on all margins, it is still too early to reject a link between rapid, late-Pleistocene sea-level rise and submarine landslide occurrence (e.g., Smith et al., 2013). Here we respond to additional points by Urlaub et al. (2014).

\section{DATABASE OF LANDSLIDE AGES}

(1) Error bars on slide ages: We used the published age-data and selected the midpoint of the uncertainty bounds. In most cases, the 4 k.y. bin widths used to compute the age distribution sufficiently covered the published range in age uncertainty.

(2) Selection of landslide age-data: A Madeira turbidite, first described in Weaver and Rothwell (1987), was given an age estimate of ca. 15 k.y. B.P. by Owen et al. (2007) based on a relative dating method. The Saharan landslide listed at 15-16 k.y. B.P. needs to be omitted in favor of the more recent estimate of ca. $60 \mathrm{ka}$. The Nice landslide was added for completeness, but had little affect the final age distribution. The four agedates reported by Embley (1982) for mass wasting to the south of Baltimore Canyon are from cores separated by more than $100 \mathrm{~km}$. New multibeam bathymetry data throughout this region (Andrews et al., 2013) has allowed us to map a complex of distinctive landslides along the slope and upper rise (e.g., Chaytor et al., 2009), thus is it unlikely the deposits described in Embley (1982) represent a single landslide. Finally, we included the Canary event in our analysis, in part, because other studies have described a causal link between volcanic activity and rapid changes in eustatic sea-level (e.g., Kutterolf et al., 2012).

\section{SLIDE FREQUENCY AND MELTWATER PULSES}

Brothers et al. (2013) referenced results from Korup (2012) for the time-cumulative volume of sediment remobilized during Late-
Pleistocene/early Holocene sea-level transgression as a percentage $(\sim 50 \%)$ of the total volume remobilized since ca. $125 \mathrm{ka}$. Meltwater pulses are associated with small increases in plate bending stress; however, we agree that any causal relationship between landslides and meltwater pulses is difficult to resolve given the uncertainties in landslide age data.

\section{MASS FLOW ACTIVITY ON SUBMARINE FANS}

Deep-water sandy turbidite activity during sea-level transgression is not an unusual observation, but is atypical within the framework provided by early sequence stratigraphic models (e.g., Kolla and Perlmutter, 1993). Our discussion of this concept seems to have been misconstrued in the comment. Interestingly, even Urlaub et al. (2013) show an apparent increase in submarine landslide frequency during latePleistocene sea-level transgression along margins characterized by relatively low terrestrial sediment input. If seismicity rates increased along continental margins during rapid sea-level transgression, earthquake-triggered landslides provide a potential source for deep-sea turbidites.

\section{REFERENCES CITED}

Andrews, B.D., Chaytor, J.D., ten Brink, U.S., Brothers, D.S., and Gardner, J.V., 2013, Bathymetric terrain model of the Atlantic Margin for marine geological investigations: U.S. Geological Survey Open-File Report 2012-1266, 11 p., doi:10.3133/ofr20121266.

Brothers, D.S., Luttrell, K.M., and Chaytor, J.D., 2013, Sea-level-induced seismicity and submarine landslide occurrence: Geology, v. 41, p. 979-982, doi:10.1130/G34410.1.

Chaytor, J.D., ten Brink, U.S., Solow, A.R., and Andrews, B.D., 2009, Size distribution of submarine landslides along the US Atlantic margin: Marine Geology, v. 264, p. 16-27, doi:10.1016/j.margeo.2008.08.007.

Embley, 1982, Anatomy of some Atlantic margin sediment slides and some comments on ages and mechanisms, in Saxov, S., and Nieuwenhuis, J.K., eds., Marine Slides and Other Mass Movements: New York, NATO Conference Series Volume 6, p. 189-213.

Kolla, V., and Perlmutter, M.A., 1993, Timing of turbidite sedimentation on the Mississippi Fan: American Association of Petroleum Geologists Bulletin, v. 77, no. 7, p. 1129-1141.

Korup, O., 2012, Earth's portfolio of extreme sediment transport events: EarthScience Reviews, v. 112, p. 115-125, doi:10.1016/j.earscirev.2012.02.006.

Kutterolf, S., Jegen, M., Mitrovica, J.X., Kwasnitschka, T., Freundt, A., and Huybers, P.J., 2012, A detection of Milankovitch frequencies in global volcanic activity: Geology, v. 41, p. 227-230, doi:10.1130/G33419.1.

Lee, H.J., 2009, Timing of occurrence of large submarine landslides on the Atlantic Ocean margin: Marine Geology, v. 264, p. 53-64, doi:10.1016/j.margeo.2008.09.009.

Luttrell, K., and Sandwell, D., 2010, Ocean loading effects on stress at near shore plate boundary fault systems: Journal of Geophysical Research. Solid Earth, v. 115, B 08411 .

Owen, M., Day, S., and Maslin, M., 2007, Late Pleistocene submarine mass movements: Occurrence and causes: Quaternary Science Reviews, v. 26, p. 958-978, doi:10.1016/j.quascirev.2006.12.011.

Smith, D.E., Harrison, S., and Jordan, J.T., 2013, Sea level rise and submarine mass failures on open continental margins: Quaternary Science Reviews, v. 82, p. 93-103, doi:10.1016/j.quascirev.2013.10.012.

Urlaub, M., Talling, P.J., and Masson, D.G., 2013, Timing and frequency of large submarine landslides: Implications for understanding triggers and future geohazard: Quaternary Science Reviews, v. 72, p. 63-82, doi:10.1016/j.quascirev.2013.04.020.

Urlaub, M., Talling, P.J., and Clare, M., 2014, Sea-level-induced seismicity and submarine landslide occurrence: Comment: Geology, v. 42, p. e337, doi:0.1130/G35254C.

Weaver, P.P.E., and Rothwell, R.G., 1987, Sedimentation on the Madeira abyssal plain over the last 300,000 years, in Weaver, P.P.E., and Thomson, J., eds., Geology and Geochemistry of Abyssal Plains: London, Geological Society of London Special Publications, v. 31, p. 71-86. 